\title{
Antecedents of Online Purchasing Intention among MBA Students: The Case of University Utara Malaysia Using the Partial Least Squares Approach
}

\author{
Abdullah Kaid Al-Swidi ${ }^{1}$, Saeed Behjati ${ }^{2}$ \& Arfan Shahzad ${ }^{3}$ \\ ${ }^{1}$ School of Quantitative Sciences, University Utara Malaysia, Sintok, Kedah, Malaysia \\ ${ }^{2}$ School of Technology Management and Logistic, University Utara Malaysia, Sintok, Kedah, Malaysia \\ ${ }^{3}$ OYA Graduate School of Business, University Utara Malaysia, Sintok, Kedah, Malaysia \\ Correspondence: Abdullah Kaid Al-Swidi, School of Quantitative Sciences, College of Arts and Sciences, \\ University Utara Malaysia, Sintok, Kedah, Malaysia. Tel: 60-12-466-2754. E-mail: swidi@uum.edu.my
}

Received: May 25, 2012

Accepted: July 20, 2012

Published: August 1, 2012

doi:10.5539/ijbm.v7n15p35

URL: http://dx.doi.org/10.5539/ijbm.v7n15p35

\begin{abstract}
The drastic increaseof the rate of internet usage has greatly influencedthe people's life style, in general, and the consumers' intentions towards online shopping behavior, in particular. This study was designed to focus on the social orientation and personal values and attitudes towards online shopping among the MBA students of the University Utara Malaysia which is known as the eminent management university. The model of this study was developed in the light of the Theory of Planned Behavior (TPB) and the data were collected from 136 MBA students whether belong to full or part time streams of study. Using the Partial Least Squares structural equation modeling as the approach to examine the model, the statistical results confirmed the positive effect of subjective norms, attitude towards online shopping behavior and the perceived behavioral control on the online purchasing intention among the MBA students. Additionally, the positive effect of perceived reliability, experience intensity and utilitarian perception on the attitude towards online shopping behavior was confirmed by the results of the study.
\end{abstract}

Keywords: online purchasing intention, theory of planned behavior (TPB), partial least squares (PLS), MBA students

\section{Introduction}

More and more manufacturers are resorting to online retailing due to its potentiality to access to specific customers' segments. Due to its convenience and speed, online shopping can suit the varieties of requirements of online customers. On the other hand, consumers' shopping habits have changed as the internet usage rate increased especially with the new generation customers (Rajamma \& Neeley, 2005;Alam et al., 2008).Internet usage has increased drastically due to the advancement of technology and communication and the level of knowledge of the new generation customers (Su \&Huang., 2011);Chen\& Chang, 2003;Morganosky\&Cude, 2000).

The Internet is one of the fastest growing media in human history which provides consumers with the opportunity to access an additional shopping medium. At present, the notion of e-commerce predominantly uses as a finding media about goods and services rather than for completing a transaction. However, online shopping is likely to increase in the availability and use of communication technologies (Rajamma\&Neeley, 2005).

According to ITU, International Telecommunication Unit, which is the United Nations specialized agency for information and communication technologies (ICTs), more than 65\% of Malaysian estimated to be internet users.In Malaysia, University Utara Malaysia has been known to be one of the eight centers of excellence of network sharing expertise, resource and capacity buildings know how from United Nations specialized agency for information and communication technologies (ICTs). Since online purchasing relies on the internet frame and 
know how knowledge, the Malaysian ICT infrastructure is expected to change greatly the future consumption styles and behavior.

The aim of this paper was mainly to examine the effect of subjective norms, attitude towards online shopping behavior and the perceived behavioral control on the online purchasing intention among the future customers as reflected by the MBA students' perceptions. Also, this study aimed to examine the effect of perceived reliability, experience intensity and utilitarian perception on the attitude towards online shopping of the future business leaders, MBA students.

\section{Theoretical Background}

The Theory of Planned Behavior (TPB), as introduced by Ajzen (1991), has been much adopted by those who study in the area of social psychology and marketing study. One key aspect of TPB is about behavioral intention, especially the intention of taking on a particular behavior or a specific product (Fattahi, 2010).

According to TPB, individual actual consumption behavior depends on consumption intention and perceived behavioral control. Moreover, the consumption intention depends on attitude (A), subjective norm ( $\mathrm{SN}$ ) and perceived behavioral control (PBC) (Fishbein \& Ajzen, 1975). Based on the philosophy of this theory, the individual behavior can be estimated and evaluated and therefore can be easily modified or changed (Wang et al., 2007).

In general, the model of this study was developed in accordance with the TPB that can account for the influence of perceived opinion of other people on the online purchasing decisions in uncertain environment (Fishbein \& Ajzen, 1975). TPB is different from the Theory of Reason Action (TRA) since it explains the actual behavior by the intention towards the behavior and the belief regarding the access to the resources required for conducting the behavior (Ajzen, 1991).This may encompass the availability of the resources and the focal person's self-confidence in the ability to conduct the behavior.

Apparently, the theory of planned behavior (TPB) has been given an increasing attention by researchers in empirical studies pertaining to social psychology and consumption (Ajzen, 1991; Ajzen \& Driver, 1992; Ajzen\& Madden, 1986).

In the literature of marketing, there are a number of streams of research addressing the factors that have significant effect on online shopping intention and actual behavior. In this research we utilize social orientation and personal valuesthat shape individual attitude toward online shopping. Apart from retesting the relationships as in the TBP, the effect of four factors namely Perceived Reliability, Experiential Intensity, Utilitarian Perception, and Hedonic Motivation on the attitude towards online shopping was examined. The factors that were utilized in this study were selected due to their potential affect as some have been studied separately in the literature (see Table 1 for reference).

Table 1. Some influential factors affecting the attitude towards online shopping behavior

\begin{tabular}{ll}
\hline Variable & \multicolumn{1}{c}{ Source } \\
\hline Perceived Reliability (trust) & Alam et al. (2008); Naveed andEddaoudi(2009); Yulihasri et al. (2011); \\
& Hsieh and Liao(2011); Jun and Jaafar (2011); Chiu et al. (2008) \\
& Naseri (2011); Hsieh and Liao(2011); MorganoskyandCude(2000) \\
Experiential intensity & Dennis et al. (2010); Liu\& Forsythe(2010) Yulihasri et al. (2011); Hsieh \\
& and Liao (2011); Jun and Jaafar (2011); Demangeotand Broderick \\
Utilitarian perception & (2007); Kim and Foresythe (2009) \\
& Dennis et al. (2010); Liu \& Forsythe(2010); Mahmoud et al. (2011); \\
& Demangeotand Broderick(2007); Chiuet al. (2008); Kim and Foresythe \\
Hedonic motivation & $(2009)$ \\
\hline
\end{tabular}

\section{Literature Review and Hypotheses Development}

As discussed earlier, this study is theoretically based on the Theory of Planned Behavior (TPB) that has been introduced by Ajzen (1991) as an extension to the Theory of Reasoned Action (TRA). The TPB accounts for the situation in which the focal people have incomplete volitional control over the resources that might affect the 
decision (Ajzen, 1991).

In the following, brief discussions are provided for the purpose of hypotheses development

\subsection{On-line Purchasing Intention}

Online marketing is an area where the concept of the traditional store marketing was altered. This area is also pertaining in depth to behavioral issues. Lack and fragment of understands of behavioral issues distinguished by success and failure of some e-retailers (Sahney et al., 2008). While most of previous researches merely focused on modeling the online buying and decision-making process (Sahney et al.., 2008), the research pertaining to behavioral issues is still lacking (Alam et al., 2008).

What leads a buyer to shop online regarding to behavioral involvement is the matter that develops an objective here to identify such factors that lead to positive attitudes of consumers toward online shopping wherein hypothesis of such factors tested and measured through structural equation modeling (SEM) analysis. Therefore the finding may be used by marketing managers and academicians for assessing on-line purchasing intention and might be, also, considered when constructing, managing, and evaluating marketing strategies.

\subsection{Subjective Norms}

Subjective norms can be defined as the perceived social pressure to perform or not perform behavior (Ajzen, 1991).Norms and social networking has influence on the individuals by transmitting information and reducing risk in their selection decisions.

The move toward online shopping in a general manner bears the significance of subjective norms in the process of decision making of consumers (Wang, 2007; Yulihasri et al., 2011). Social normative influence could be of high importance to a consumer when considering an online buying (Hansen, 2008), therefore it can be hypothesized that upon having a positive subjective norm; consumers are more likely to do online shopping. Thus the following hypothesis can be empirically tested.

\section{H1: subjective norms have a positive significant impact on On-line purchasing intention}

\subsection{Attitude}

Consumer's attitude based on the theory of planned behavior is perceived favorable or unfavorable feeling when someone is doing something. It is a predictive of the person's intention to engage in a particular behavior(Ajzen, 1991).It has been widely indicated that positive or negative attributes of a certain behavior let individuals to automatically bring forth an attitude toward the behavior itself (Ajzen, 1991).

Many researchers (such as Wang, 2007;Abdul-Muhmin, 2011) found that the attitude toward the online shopping behavior significantly influenced onlineshopping behavior while some others, like Hansen , (2007), believes thatthis relationship should be moderated by experience.

Based on the previous arguments and other supporting ones, it is reasonable to postulate the following testable hypothesis:

\section{H2: The individual's attitudeson online shopping behavior has a positive significant effect on On-line purchasing intention}

\subsection{Perceived Behavioral Control}

As defined by Ajzen and Madden (1986), perceived behavioral control reflects someone's perception on the availability of resources or opportunities of performing a behavior, i.e. consumer's judgment on his own feasible consumption degree. Existing literatures about social psychology on behavioral studies postulated that Attitudes have been indicated to be significant predictors of treatment, the intention to do the behavior and explicative elements of alternatives in particular person's behavior (Fattahi,2010;Hsieh \& Liao, 2011). According to Wang (2007) and Hsieh and Liao (2011), perceived behavior control has a significant influence on the individual's shopping online behavior.

Therefore, the following hypothesis aims to examine empirically this relationship as postulated in the following:

\section{H3: perceived behavioral control has a positive significant effect on theOn-line purchasing intention}

\subsection{Perceived Reliability}

The previous research has clearly illustrated the importance of security pertains to trust and confidence in the issues of transaction medium and privacy (Sahney et al., 2008). The issues of trust, confidence and risk are always present in the buyers' mind. What consumers apparently concern is to receive the right quality and the right quantity within the promised time frame (Alam et al., 2008). The study carried out by Naveed and 
Eddaoudi (2009) specified that trust in online retailing context is related to any relationship between the online seller and buyer.

Severalother studies (such as Chiu et al., 2008; Jun and Jaafar, 2011; Hsieh and Liao, 2011; Alam et al., 2008; Yulihasri et al., 2011) demonstrated the importance of trust as a substantial factor that positively impacts the online shopping behavior. They, moreover, argued that perceived reliability or trust on the internet is the basis for customers' involvement in onlineshopping. This trust can be a normal result of the willingness of the seller to provide a safe environment for online transaction until the product delivery moment.

In the context of growth of electronic commerce and telecommunication knowledge, the motion of reliability needs to be investigated. Thus, the Perceived Reliability factors were selected as part of the study in hand.

From the preceding discussion, the following hypotheses can be deduced:

\section{H4: perceived Reliability has a positive significant effect on the attitude towards on-line shopping}

\subsection{Experience Intensity}

According to Naseri (2011) having prior experience on shopping online would significantly decrease the amount of time and cognitive efforts involved in both learning and conducting web shopping.Similarly, Hsieh and Liao (2011) argued that experience reduce the time needed to navigate and search for information therefore increasing the probability of online purchase. However, experimental dimensions of the site is its ability to produce an involving shopping experience, it enables shoppers to further explore their shopping interests or needs. Furthermore, Morganosky and Cude (2000) noted that online shopping has been more common among those who have experience on purchasing online. These arguments lead to hypothesizing the following hypothesis to be examined:

\section{H5: Experiential intensity has positive significant effect on the attitude towards on-line shopping}

\subsection{Utilitarian Perception}

Purchasing online may provide values not available from other channels such as convenience, less physical effort, broad product selection and availability (Liu \& Forsythe, 2010). Many studies, however, showed that perceived Utilitarian significantly enhancesthe consumer intentions towards online shopping and willingness to purchase from the site (Dennis et al., 2010). Several authors utilize factors as a benchmark to measure the utilitarian perception such as usability, ease of use, response time, site fundability and accessibility, convenience design and efficiency (Demangeot \& Broderick, 2007; Jun \& Jaafar, 2011; Kim and Foresythe, 2009). In addition to that, usefulness has been found to be linked with utilitarian shoppers and its influence on the attitude towards online shopping has been confirmed (Liu \& Forsythe, 2010; Yulihasri et al., 2011). In other words, consumers seek value through the shopping process; thus, Utilitarian perception is a significant criterion to shopping online.Based on the previous discussion, this study aims to examining the following hypothesis:

\section{H6: Utilitarian perception has a positive significant impact on theattitude towards on-line shopping}

\subsection{Hedonic Motivation}

Perception of hedonic and enjoyment associated with shopping online laying emphasis on the hedonic pleasures (Sahney et al., 2008).Some studies such as conducted by Liu and Forsythe(2010); Kim and Eastin (2011) indicated that an enjoyable experience influences consumer adoption of Internet devices. Since consumers pursue both utilitarian and hedonic value through shopping, this feeling evoked online retailers. In other words, rich shopping environment influence shopping experience of the customer. To confirm the effect of hedonic motivation on the online shopping behavior, the following hypothesis was introduced to be tested:

\section{H7: Hedonic motivation has a positive significant effect on the attitude towards On-line shopping}

\section{Research Framework}

Based on the literature review and the process used to develop the hypotheses of the study, Figure 1 illustrates the research framework and the hypotheses this study aimed to empirically test. 


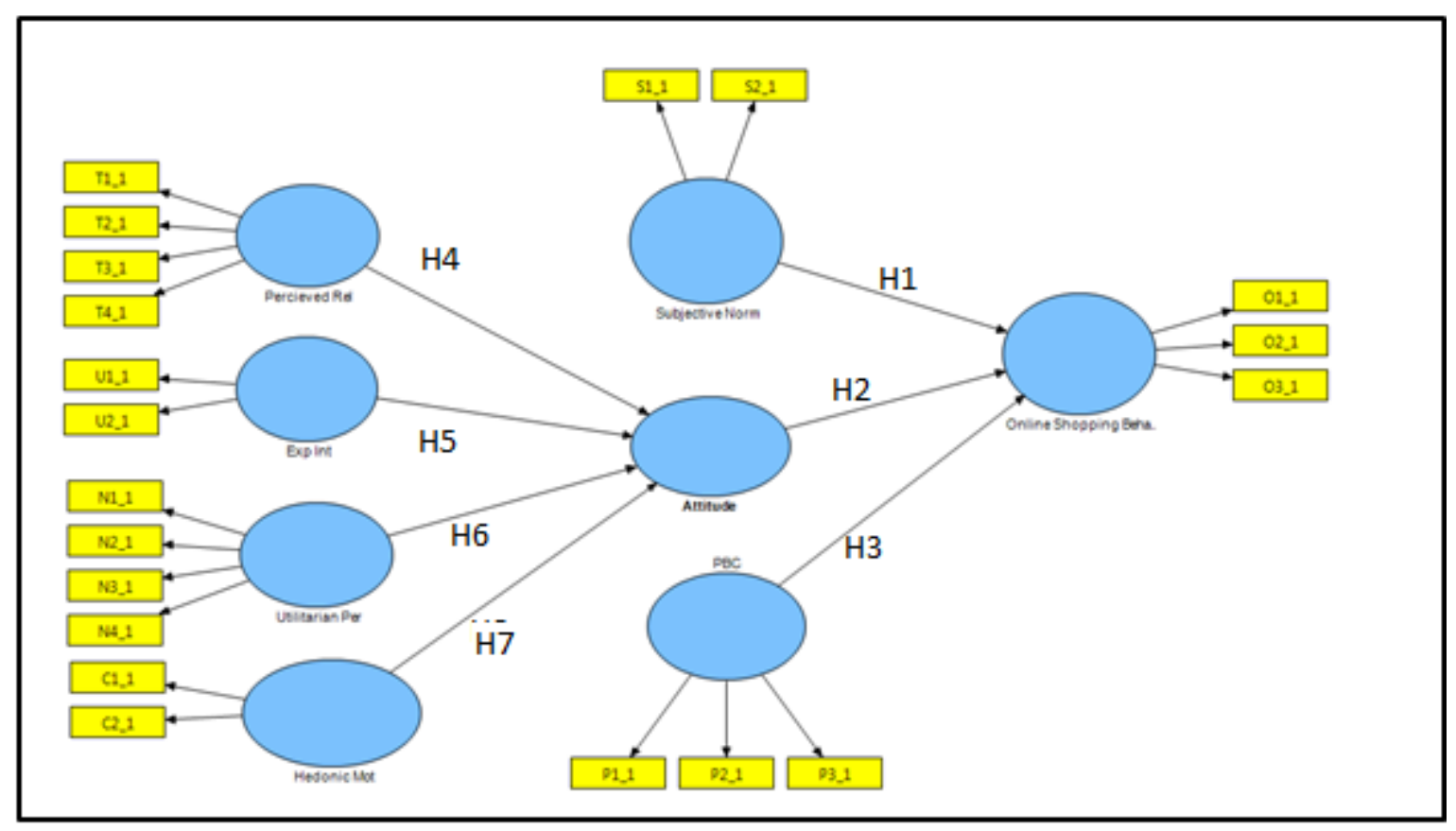

Figure 1. Research framework

\section{Research Design and Methodology}

\subsection{Instrument and Measurement of the Variables}

The questionnaire was pre-tested within expert in quantitative science field to prevent any vagueness and misunderstanding of wording and sequence of the questions.

All the items were utilized using a seven point Likert scale anchored between "Strongly Disagree (1)" and "Strongly Agree (7)".

It may be noted that the scale items used in the instrument were books, Music CD's, Software, DVD \& videotapes, Cloths, Sport equipments and others which were measuring online shopping orientation. In addition, several demographic variables such as gender, age, race, Internet usage rate and Frequency purchase online, Type of products bought over internet were also measured.

\subsection{Sampling and Data Collection Procedures}

For the purpose of this study, the data was collected based on the survey questionnaire distributed to the MBA students. The email list of MBA students of UUM was utilized. In UUM, there are currently 1173 MBA students in both full time and part time streams of study. Based on the sampling frame obtained from the UUM, the questionnaire was made available online and was sent to all the students in the list to have a random sample of the usable questionnaires. Students were requested to respond to the questionnaire and send them back by email. Out of the distributed questionnaires, 156 questionnaires were returned out of which only 136 were usable.

\subsection{Non-response Bias}

As argued by Armstrong and Overton (1977) and Kannan et al. (1999) that the late respondents who responded after many reminders can be considered as the non-respondents. This study examined the non-response bias by following the method suggested by Armstrong and Overton (1977) and Kannan et al. (1999) by testing the differences between the responses of the early and late respondents. If differences between late and early respondent were found to be significant, this may reflect the underlying differences between respondents and non-respondents.

In the study, the $\mathrm{T}$ test was used to investigate the difference between the early and late respondents regarding all the variables of the study. A number of 92 questionnaires were received without sending the reminder whereas 44 were received after sending the online questionnaire once again to the students' list. Based on the $\mathrm{T}$ test conducted using IBM SPSS version 19.0, the differences between the responses of the two groups of respondents 
regarding all the variables were not statistically significant indicating the absence of the issue of the non-response bias.

\subsection{Profile of the Respondents}

As illustrated in Table 2, respondents were equally distributed based on their gender while $50.7 \%$ were males, $49.3 \%$ were females. Of course, since the targeted sample was focused on MBA students, more than half of the surveyed students, $59.6 \%$, were less than 30 years of age and $40.4 \%$ of them were more than 30 and these are mainly the part timer students who are already having jobs.

The results also showed that the majority of the students were Malay with $64.7 \%$ and the rest distributed as $8.8 \%, 7.4 \%$, and $19.1 \%$ for Chinese, Indians, and others respectively.

With respect to the internet usage and items purchased online, the results showed that more than $91 \%$ of the sample they have been using the internet for more than 4 years. Furthermore, the most frequent purchased items were the clothes with $44.1 \%$ and books came at the third order with only $14.7 \%$. Table 2 detailed the results related to the sample distribution according to some variables of interest.

Table 2. Respondents' profile

\begin{tabular}{|c|c|c|c|}
\hline Variable & Descriptions & Frequency & $\%$ \\
\hline \multirow[t]{2}{*}{ Gender } & Male & 69 & 50.7 \\
\hline & Female & 67 & 49.3 \\
\hline \multirow[t]{4}{*}{ Race } & Malay & 88 & 64.7 \\
\hline & Chinese & 12 & 8.8 \\
\hline & Indians & 10 & 7.4 \\
\hline & others & 26 & 19.1 \\
\hline \multirow[t]{2}{*}{ Age } & Less than 30 & 81 & 59.6 \\
\hline & More than 30 & 55 & 40.4 \\
\hline \multirow[t]{4}{*}{ Internet Usage Duration } & $<6$ months & 1 & 0.7 \\
\hline & $1-3$ years & 10 & 7.4 \\
\hline & years & 38 & 27.9 \\
\hline & $>=7$ years & 87 & 64.0 \\
\hline \multirow[t]{7}{*}{ Type of products bought over internet } & Books & 20 & 14.7 \\
\hline & Music CD & 1 & 0.7 \\
\hline & Softwares & 9 & 6.6 \\
\hline & $\begin{array}{l}\text { DVD } \\
\text { videotapes }\end{array}$ & 5 & 3.7 \\
\hline & Clothes & 60 & 44.1 \\
\hline & Sports'equipments & 4 & 2.9 \\
\hline & Others & 26 & 19.1 \\
\hline
\end{tabular}

\subsection{Goodness of the Measure and Data Analysis Procedures}

The performed inspection of multivariate kurtosis statistics revealed that the data could not meet the normality assumption which is the base for Maximum Likelihood Estimation (MLE), the method of estimation on which covariance based SEM is built. The violation of the multivariate normality assumption was indicated by the Mardia's (1970) coefficient of multivariate kurtosis which was calculated AMOS (Arbuckle, 2006). The Mardia's coefficient was found to be 106.075 with critical ratio 16.210 exceeding the cut-off value of 5.0 as suggested by Bentler (2006). This result revealed that multivariate normality assumption was not tenable.

In addition to that, the number of parameters to be estimated based on AMOS package was 106 that require at least five times this number, 530, to be the minimum sample size required if the AMOS to be used (Kline, 2011). 
Due to these two main reasons, we resorted to the Partial Least Squares (PLS) path modeling algorithm which is characterized to be distribution free statistical modeling technique with less demand regarding the sample size required (Chin, 1998). Therefore, this study employed SmartPLS 2.0 for the data analysis purpose.

\subsubsection{Validity and Reliability of the Measures}

The goodness of the measure of this study was established through the reliability and construct validity. Construct validity concerns the appropriateness and validity of the measure in testing the theory it was designed to test. Relatedly, the reliability of the measure concerns the consistency of the measure in measuring the concept of concern(Sekaran \& Bougie, 2010).

\subsubsection{Construct Validity}

As discussed earlier, construct validity refers to the extent to which the measure fits the theory based on which the measure was designed (Sekaran\&Bougie, 2010). Meaning that, the concern of the construct validity is whether the instrument taps the hypothesized concept.To validate the measures of the study, the convergent and discriminant validity were thoroughly investigated and the results were reported as discussed in the following.

\subsubsection{Convergent Validity and Reliability}

The convergent validity of the measure is defined as the degree to which a set of items converge consistently to measure a particular concept. It can be measured through the factor loadings, composite reliability (CR) and average variance extracted (AVE) criteria (Hair et al., 2010). To establish that, we examined the items' factor loadings and cross loadings to identify if there are problems related to some items. The cutoff value of 0.5 , as suggested by (Hair et al., 2010), was used to assess the goodness of items' loadings. As exhibited in Table 3, all the items' loading exceeded the recommended value of 0.5 (Hair et al., 2010). In other words, results in Table 3 shows that all the items highly loaded on their respective factors when compare to their loadings on other factors.

Table 3. Loadings and cross loadings

\begin{tabular}{lllllllll}
\hline Items & Attitude & $\begin{array}{l}\text { Hedonic } \\
\text { Motivation }\end{array}$ & $\begin{array}{l}\text { Utilitarian } \\
\text { Perception }\end{array}$ & $\begin{array}{l}\text { Online } \\
\text { Shopping } \\
\text { Behavior }\end{array}$ & $\begin{array}{l}\text { Perceived } \\
\text { Behavior } \\
\text { Control }\end{array}$ & $\begin{array}{l}\text { Subjective } \\
\text { Norm }\end{array}$ & $\begin{array}{l}\text { Perceived } \\
\text { Reliability }\end{array}$ & $\begin{array}{l}\text { Experiential } \\
\text { intensity }\end{array}$ \\
\hline A1_1 & 0.880 & 0.251 & 0.504 & 0.336 & 0.179 & 0.302 & 0.492 & 0.239 \\
A2_1 & 0.825 & 0.110 & 0.544 & 0.199 & 0.149 & 0.279 & 0.422 & 0.207 \\
A3_1 & 0.849 & 0.411 & 0.338 & 0.464 & 0.314 & 0.468 & 0.585 & 0.317 \\
A4_1 & 0.793 & 0.078 & 0.411 & 0.321 & 0.143 & 0.260 & 0.502 & 0.180 \\
C1_1 & 0.207 & 0.876 & 0.178 & 0.625 & 0.636 & 0.370 & 0.272 & -0.197 \\
C2_1 & 0.274 & 0.932 & 0.312 & 0.559 & 0.702 & 0.518 & 0.388 & -0.012 \\
N1_1 & 0.573 & 0.321 & 0.933 & 0.338 & 0.313 & 0.650 & 0.475 & 0.353 \\
N2_1 & 0.452 & 0.317 & 0.948 & 0.242 & 0.255 & 0.521 & 0.357 & 0.340 \\
N3_1 & 0.482 & 0.206 & 0.909 & 0.268 & 0.354 & 0.378 & 0.382 & 0.255 \\
N4_1 & 0.391 & 0.157 & 0.868 & -0.041 & 0.124 & 0.409 & 0.301 & 0.426 \\
O1_1 & 0.262 & 0.660 & 0.209 & 0.904 & 0.704 & 0.451 & 0.508 & -0.133 \\
O2_1 & 0.539 & 0.278 & 0.405 & 0.752 & 0.424 & 0.430 & 0.481 & 0.141 \\
O3_1 & 0.264 & 0.675 & 0.010 & 0.881 & 0.613 & 0.274 & 0.382 & -0.164 \\
P1_1 & 0.200 & 0.762 & 0.355 & 0.656 & 0.908 & 0.354 & 0.273 & -0.143 \\
P2_1 & 0.265 & 0.713 & 0.345 & 0.574 & 0.926 & 0.336 & 0.281 & -0.141 \\
P3_1 & 0.138 & 0.334 & -0.006 & 0.497 & 0.648 & 0.345 & 0.354 & -0.101 \\
S1_1 & 0.407 & 0.529 & 0.479 & 0.459 & 0.412 & 0.953 & 0.704 & 0.166 \\
S2_1 & 0.345 & 0.408 & 0.559 & 0.396 & 0.362 & 0.936 & 0.562 & 0.270 \\
T1_1 & 0.469 & 0.340 & 0.444 & 0.340 & 0.295 & 0.610 & 0.821 & 0.161 \\
T2_1 & 0.439 & 0.189 & 0.318 & 0.360 & 0.239 & 0.642 & 0.814 & 0.199 \\
T3_1 & 0.568 & 0.299 & 0.311 & 0.568 & 0.319 & 0.504 & 0.849 & -0.042 \\
T4_1 & 0.540 & 0.408 & 0.359 & 0.514 & 0.336 & 0.545 & 0.881 & -0.130 \\
U1_1 & 0.178 & -0.020 & 0.248 & -0.102 & -0.187 & 0.174 & -0.066 & 0.907 \\
U2_1 & 0.325 & -0.138 & 0.409 & -0.049 & -0.126 & 0.238 & 0.096 & 0.973 \\
\hline
\end{tabular}

Next, the composite reliability was examined as an important aspect of convergent validity. The composite reliability refers to the extent to which a set of items indicates consistently the latent construct (Hair et al., 2010). 
As illustrated in Table 4, the composite reliability ranged from 0.884 to 0.954 which exceeds the recommended value of 0.7 thus indicates an adequate convergent validity (Fornell\&Larcker, 1981; Hair et al., 2010).

Additionally, the average variance extracted (AVE), which refers to the average variance extracted among a set of items, was examined. In fact, AVE can be used to compare the variance captured by the indicators with the variance assignable to the measurement errors. As suggested by Barclay et al. (1995), values of AVE higher than 0.5 indicate that the set of items has an adequate convergence in measuring the concern construct.Based on the results of Table 3, the values of average variances extracted (AVE) of all the constructs were ranged between 0.701 and 0.891 . Thus the measures used have an adequate level of convergent validity.

Table 4. Results of measurement model

\begin{tabular}{|c|c|c|c|c|c|}
\hline Model Construct & $\begin{array}{l}\text { Measurement } \\
\text { items }\end{array}$ & Loading & $\begin{array}{l}\text { Cronbach's } \\
\text { Alpha }\end{array}$ & $\mathrm{CR}^{\mathrm{a}}$ & $\mathrm{AVE}^{\mathrm{b}}$ \\
\hline \multirow[t]{4}{*}{ Attitude } & A1_1 & 0.880 & 0.858 & 0.904 & 0.701 \\
\hline & A2_1 & 0.825 & & & \\
\hline & A3_1 & 0.849 & & & \\
\hline & A4_1 & 0.793 & & & \\
\hline \multirow[t]{2}{*}{ Hedonic Motivation } & C1_1 & 0.876 & 0.782 & 0.900 & 0.818 \\
\hline & $\mathrm{C} 2 \_1$ & 0.932 & & & \\
\hline \multirow[t]{4}{*}{ Utilitarian Perception } & N1_1 & 0.933 & 0.935 & 0.954 & 0.837 \\
\hline & $\mathrm{N} 2 \_1$ & 0.948 & & & \\
\hline & N3_1 & 0.909 & & & \\
\hline & N4_1 & 0.868 & & & \\
\hline \multirow[t]{4}{*}{ Online Shopping Behavior } & & & 0807 & 0884 & 0710 \\
\hline & O1_1 & 0.904 & 0.002 & 0.004 & 0.113 \\
\hline & $\mathrm{O} 2 \_1$ & 0.752 & & & \\
\hline & O3_1 & 0.881 & & & \\
\hline \multirow{4}{*}{$\begin{array}{l}\text { Perceived } \\
\text { Control }\end{array}$} & & & & & \\
\hline & P1_1 & 0.908 & 0.773 & 0.873 & 0.701 \\
\hline & P2_1 & 0.926 & & & \\
\hline & P3_1 & 0.648 & & & \\
\hline \multirow[t]{2}{*}{ Subjective Norm } & $\mathrm{S} 1 \_1$ & 0.953 & 0.879 & 0.943 & 0.891 \\
\hline & S2_1 & 0.936 & & & \\
\hline \multirow[t]{4}{*}{ Perceived Reliability } & T1_1 & 0.821 & 0.864 & 0.907 & 0.709 \\
\hline & T2_1 & 0.814 & & & \\
\hline & T3_1 & 0.849 & & & \\
\hline & T4_1 & 0.881 & & & \\
\hline \multirow[t]{2}{*}{ Experiential intensity } & U1_1 & 0.907 & 0.880 & 0.939 & 0.885 \\
\hline & U2_1 & 0.973 & & & \\
\hline
\end{tabular}

\section{Note:}

${ }^{\text {a }}$ Composite Reliability $(\mathrm{CR})=$ (square of the summation of the factor loadings) $/$ \{(square of the summation of the factor loadings $)+($ summation of the error variances $)\}$

${ }^{\mathrm{b}}$ Average Variance Extracted $(\mathrm{AVE})=$ (summation of the square of the factor loadings $) /\{$ (summation of the square of the factor loadings) + (summation of the error variances) $\}$ 
In assessing the measurement model, results in Table 5 summarize the findings related to the main constructs of the study namely, Attitude, Hedonic Motivation, Utilitarian Perception, Online shopping behavior, Perceived behavioral control, Subjective norm, Perceived reliability, and experiential intensity. As indicated by the results in Table 4, all the eight constructs have shown an adequate level of validity in measuring their respective constructs since they showed a statistical significance of the loadings (Chow \& Chan, 2008).

Table 5. Summary results of the model construct

\begin{tabular}{|c|c|c|c|}
\hline Model Construct & $\begin{array}{l}\text { Measurement } \\
\text { items }\end{array}$ & $\begin{array}{l}\text { Standardized } \\
\text { Estimates }\end{array}$ & T- Value \\
\hline \multirow[t]{4}{*}{ Attitude } & A1_1 & 0.880 & 13.875 \\
\hline & A2_1 & 0.825 & 10.046 \\
\hline & A3_1 & 0.849 & 13.805 \\
\hline & A4_1 & 0.793 & 12.402 \\
\hline \multirow[t]{2}{*}{ Hedonic Motivation } & $\mathrm{C} 1 \_1$ & 0.876 & 3.298 \\
\hline & $\mathrm{C} 2 \_1$ & 0.932 & 6.494 \\
\hline \multirow[t]{4}{*}{ Utilitarian Perception } & N1_1 & 0.933 & 14.918 \\
\hline & N2_1 & 0.948 & 19.529 \\
\hline & N3_1 & 0.909 & 15.382 \\
\hline & N4_1 & 0.868 & 11.399 \\
\hline \multirow[t]{3}{*}{ Online Shopping Behavior } & O1_1 & 0.904 & 16.141 \\
\hline & O2_1 & 0.752 & 11.692 \\
\hline & O3_1 & 0.881 & 14.809 \\
\hline \multirow[t]{3}{*}{ PerceivedBehavior Control } & P1_1 & 0.908 & 17.640 \\
\hline & P2_1 & 0.926 & 15.855 \\
\hline & P3_1 & 0.648 & 11.260 \\
\hline \multirow[t]{2}{*}{ Subjective Norm } & S1_1 & 0.953 & 17.078 \\
\hline & S2_1 & 0.936 & 16.736 \\
\hline \multirow[t]{4}{*}{ Perceived Reliability } & T1_1 & 0.821 & 12.497 \\
\hline & $\mathrm{T} 2 \_1$ & 0.814 & 14.997 \\
\hline & T3_1 & 0.849 & 13.088 \\
\hline & T4_1 & 0.881 & 11.151 \\
\hline \multirow[t]{2}{*}{ Experiential intensity } & U1_1 & 0.907 & 2.836 \\
\hline & U2_1 & 0.973 & 6.618 \\
\hline
\end{tabular}

\subsubsection{Discriminant Validity}

The next step was to examine the discriminant validity of the measures. The discriminant validity of the measures refers to the degree to which items can differentiate among constructs. Meaning that, the items measuring constructs don't overlap.To say the same in different way, a particular construct shares higher variance with its own items than other constructs' items (Compeau et al., 1999).The discriminant validity of the measures was 
examined by following the method suggested by Fornelland Larcker (1981). In this method, the square root of average variance extracted (AVE) should be higher than the cross correlation among constructs.As illustrated by Table 6, the diagonal elements, which are the square root of the AVE for each construct, is higher than the cross correlation between that construct and other constructs. Thus, these results demonstrated adequate discriminant validity. From the convergent validity and construct validity analysis, the construct validity of the measure can be concluded.

Table 6. Mean, standard deviation and the results of the discriminant validity of constructs

\begin{tabular}{lccccccccccc}
\hline Model Construct & & Mean & Stddev & 1 & 2 & 3 & 4 & 5 & 6 & 7 & 8 \\
\hline Attitude & $(1)$ & 3.985 & 1.008 & 0.837 & & & & & & & \\
Experiential intensity & $(2)$ & 2.379 & 1.576 & 0.287 & 0.941 & & & & & & \\
Hedonic Motivation & $(3)$ & 4.152 & 1.152 & 0.270 & -0.101 & 0.905 & & & & & \\
Online Shopping Behavior & $(4)$ & 4.009 & 0.917 & 0.406 & -0.072 & 0.647 & 0.848 & & & & \\
Perceived Behavior Control & $(5)$ & 4.284 & 1.194 & 0.243 & -0.155 & 0.741 & 0.694 & 0.837 & & & \\
Perceived Reliability & $(6)$ & 4.136 & 0.979 & 0.604 & 0.041 & 0.372 & 0.539 & 0.356 & 0.842 & & \\
Subjective Norm & $(7)$ & 3.912 & 1.148 & 0.400 & 0.227 & 0.500 & 0.455 & 0.412 & 0.675 & 0.944 & \\
Utilitarian Perception & $(8)$ & 3.673 & 1.193 & 0.527 & 0.371 & 0.280 & 0.239 & 0.295 & 0.422 & 0.546 & 0.915 \\
\hline
\end{tabular}

\subsection{Global Fit Measures (GoF)}

As defined by Tenenhaus et al. (2004), a global fit measure (GoF) for PLS path modeling is the geometric mean of the average communality and average $\mathrm{R}^{2}$ for the endogenous constructs. To support the validity of the PLS model, GoF value was estimated according to the guidelines set up by Wetzels et al. (2009). In our study, the obtained GoF value was 0.676 that exceeds the cut-off value of 0.36 for large effect sizes of $\mathrm{R}^{2}$. The comparison was made with the baseline values of $\mathrm{GoF}$ ( small $=0.1$, medium $=0.25$, large $=0.36$ ) as suggested by Wetzels et al. (2009) providing evidence of adequate of global PLS model validity.

\subsection{Predictive Relevance of the Model}

As discussed earlier, the magnitude of the $\mathrm{R}^{2}$ for the endogenous variables is an indicator of predictive power of the model. To confirm the predictive relevance of the model, the sample reuse technique was applied as suggested by Stone (1974) and Geisser (1975). In fact, the sample's reuse technique was argued by Wold (1982) to fit very well the PLS modeling approach (Götz, Liehr-Gobbers, \& Krafft, 2011).

More specifically, we next examined the predictive validity of the model through the procedures suggested by Stone-Geisser non-parametric test (Geisser, 1975; Stone, 1974; Fornell\& Cha, 1994; Chin, 1998). To achieve this purpose, the blindfolding procedures incorporated in Smart-PLS package were used. Blindfolding procedures is designed to remove some data and then estimate them as missing values.Based on that, the blindfolding procedure produce general cross-validating metrics $\mathrm{Q}^{2}$.

Based on these procedures, there are different forms of $Q^{2}$ that can be calculated based on the form of desired prediction. A cross-validated communality $\mathrm{Q}^{2}$ can be obtained when the data points predicted based on the latent variable scores. From another perspective, when the data points are obtained by the LVs that predict the block in question, a cross-validated redundancy $\mathrm{Q}^{2}$ is the output. The cross-validated redundancy measure can be a reliable measure of the predictive relevance of the model investigated (Fornell \& Cha, 1994). If the test criterion, redundant communality was found to be larger than 0 for all the endogenous variables, the model is considered to have predictive validity, otherwise, the predictive relevance of the model cannot be concluded (Fornell \& Cha, 1994). The results of our model indicate that the cross-validated redundancy for Attitude and online shopping behavior were respectively 0.315 and 0.381 more than zero. Thus the predictive validity of the used model was established.

\subsection{Testing the Research Model}

Next, we tried to analyze the path analysis results to test the hypotheses articulated in the research model of the study. As the results in Figure 2 showed that the $\mathrm{R}^{2}$ value of the Online shopping behavior was 0.554indicating the $55.4 \%$ of the variance in the online shopping behavior construct is explained by the Subjective norm, Attitude and Perceived behavioral control. Additionally, the $\mathrm{R}^{2}$ value of Attitude was 0.481 indicating that $48.1 \%$ 
of the variance is explained by the Hedonic Motivation, Utilitarian Perception, Perceived reliability and Experiential Intensity. Both values of $\mathrm{R}^{2}$ indicated the significant importance of the predictor variables to the respective criterion variable. More specifically, Hedonic Motivation, Utilitarian Perception, Perceived reliability and Experiential Intensity have a significant impact on the Attitude that has, in turn, a significant impact on online shopping behavior.

The results of the study showed that Perceived reliability, Experiential intensity and Utilitarian Perception were found to have a positive significant effect on the Attitude towards online shopping behavior with indicators $(\beta=$ 0.477 , $t$-value $=6.837, p<0.001),(\beta=0.180$, t-value $=2.731, p<0.01) \quad$ and $(\beta=0.247, t$-value $=3.234, p<0.001)$ respectively. These results indicated that $\mathrm{H} 4$ through $\mathrm{H} 6$ were supported by the results of the study. On the other hand, Hedonic motivation was found to be insignificant predictor of Attitude towards online shopping behavior $(\beta=0.042$, $\mathrm{t}$-value $=0.612, \mathrm{p}>0.05)$. Thus hypothesis $\mathrm{H} 7$ was not statistically supported by the results of this study.

The next step was to test the remaining three hypotheses related to the effect of Subjective norm, Attitude and Perceived behavioral control on the online shopping behavior. The results of the study confirmed the positive significant effect of the three variables with indicators $(\beta=0.128$, t-value $=2.338, p<0.05),(\beta=0.212, t$-value $=$ $3.691, \mathrm{p}<0.001)$ and $(\beta=0.690, \mathrm{t}$-value $=11.906, \mathrm{p}<0.001)$ respectively. Thus the hypotheses H1 through H3 were supported by the results of the study. These results, moreover, confirm the importance of these three variables in explaining the variance in the online shopping behavior in the light of the theory of planned behavior. Table 7, Figure 2 and Figure 3; however, summarize the results related to the hypotheses of the study.

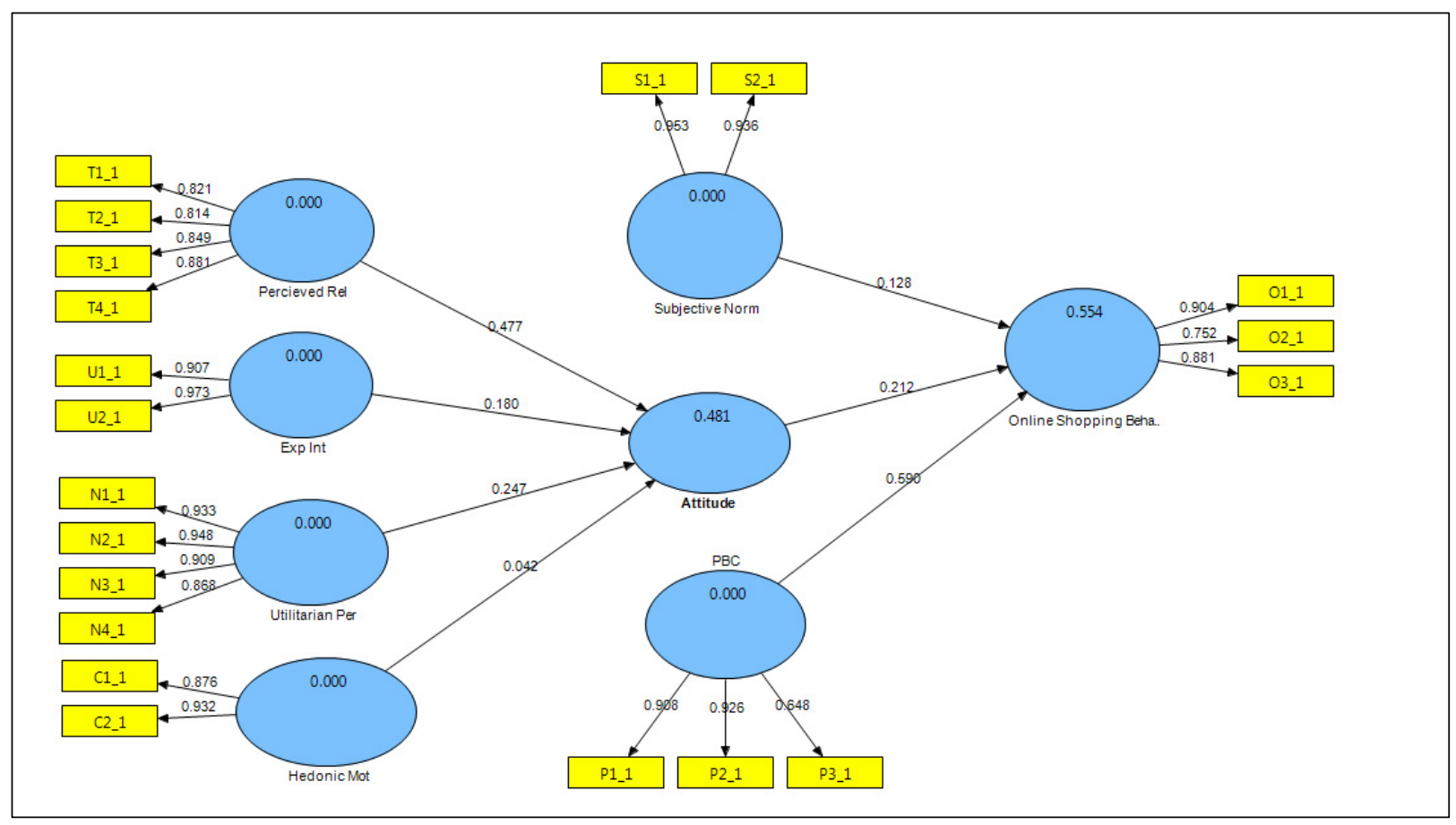

Figure 2. Path analysis results 


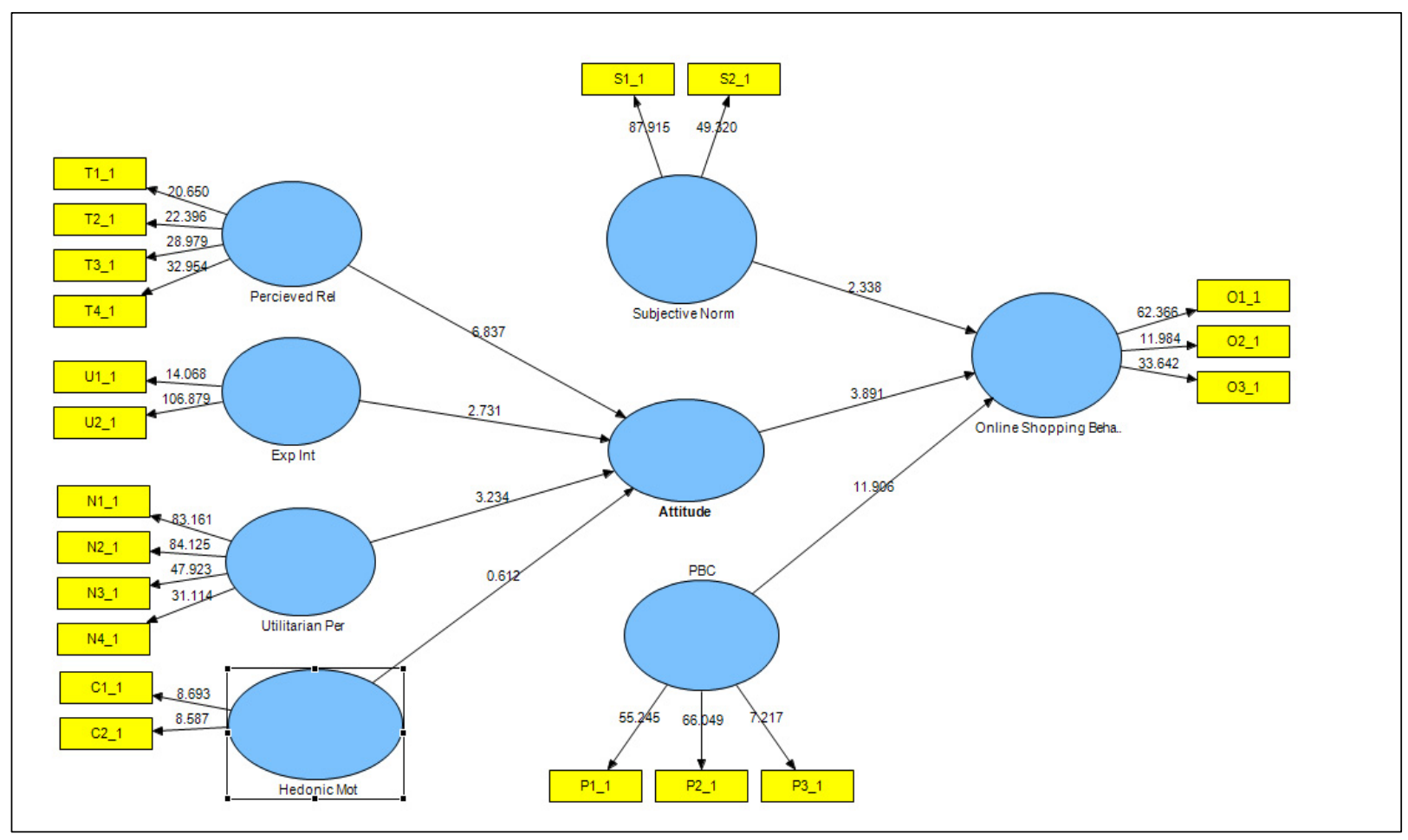

Figure 3. T-Values for the Path Analysis Results

Table 7. Path coefficients and hypothesis testing

\begin{tabular}{|c|c|c|c|c|}
\hline Hyp & Relationship & $\begin{array}{l}\text { Path } \\
\text { Coefficient }\end{array}$ & $\mathrm{T}$ value & Decision \\
\hline H1 & Subjective norm --> Online shopping behavior & $0.128^{*}$ & 2.338 & Supported \\
\hline $\mathrm{H} 2$ & $\begin{array}{l}\text { Attitude towards online shopping --> Online } \\
\text { shopping behavior }\end{array}$ & $0.212 * * *$ & 3.891 & Supported \\
\hline $\mathrm{H} 3$ & $\begin{array}{l}\text { Perceived behavioral control --> Online } \\
\text { shopping behavior }\end{array}$ & $0.590 * * *$ & 11.906 & Supported \\
\hline $\mathrm{H} 4$ & $\begin{array}{l}\text { Perceived reliability --> Customers' attitude } \\
\text { towards online shopping }\end{array}$ & $0.477 * * *$ & 6.837 & Supported \\
\hline H5 & $\begin{array}{l}\text { Experience intensity --> Customers' attitude } \\
\text { towards online shopping }\end{array}$ & $0.180^{*}$ & 2.731 & Supported \\
\hline H6 & $\begin{array}{l}\text { Utilitarian perception --> Customers' attitude } \\
\text { towards online shopping }\end{array}$ & $0.247 * * *$ & 3.234 & Supported \\
\hline $\mathrm{H} 7$ & $\begin{array}{l}\text { Hedonic motivation --> Customers' attitude } \\
\text { towards online shopping }\end{array}$ & 0.042 & 0.612 & $\begin{array}{c}\text { Not } \\
\text { Supported }\end{array}$ \\
\hline
\end{tabular}

$* * *: \mathrm{p}<0.001, * *: \mathrm{p}<0.01, *: \mathrm{p}<0.05$

\section{Discussion, Conclusion and Implication}

Due to the ongoing ICT revolution reflected in the rapid advancements of technology and information frames, retailing has witnessed a dramatic shift from the traditional store-based shopping to during the o'clock 
web-based retailing. Additionally, the wave of globalization has changed the form of all the operations including the consumption styles of the customers. Due to that, customers can seek their choices regarding the specifications and functionality online within a large pool of global products portfolio.

The statistical results were, in general, consistent with the previous findings related to the online shopping intention of the customers. The results showed that subjective norms have a significant influence on the decision making process, in general, and online shopping intention in particular. These results are in line with the findings of Wang (2007) and Yulihasri et al. (2011). In a similar way, the results of the study confirmed the role of attitude towards the intention to online shopping. These findings corroborated the findings of many researchers (such as Wang, 2007; Abdul-Muhmin, 2011). Our results, moreover, concluded the significant effect of perceived behavior control on the intention to shop online. This conclusion is in line with that of Wang (2007) and Hsieh and Liao (2011). In general, the positive significant effect of the subjective norms, attitude towards online shopping and the perceived behavioral control was confirmed indicating the higher the level of these variables, the higher the customer's intention to shop online. In addition to that, the perceived behavior control has the highest power in predicting the intention to online shopping when compared to the subjective norms and the attitude of customers towards online shopping.

The results of this study also show that perceived reliability significantly affect the customers' attitude towards online shopping. These findings were in line with the previous research that have clearly illustrated the importance of security pertains to trust and confidence in the issues of transaction medium and privacy (Sahney et al., 2008). The main concern of the customers is to receive the right quality and the right quantity within the promised time frame (Alam et al., 2008). The study carried out by Naveed and Eddaoudi(2009) specified that the trust in online retailing can influence the customers' online shopping decisions.

This study, moreover, confirmed the positive impact of experience on the customers' intention towards online shopping. This findings goes well with the argument made by Hsieh and Liao(2011) that experience can reduce the time needed to search for information and then subsequently increase the likelihood of online purchase. Additionally, it was argued by Morganosky and Cude(2000) that the more experience is the customer in shopping online, the more will be his intention to purchasing online.

This study has confirmed the findings of the previous research with regards to the effect of utilitarian perception on the consumers' decision related to the online shopping.In addition to that, usefulness has been found to be linked with perceived utilitarian and its influence on the customers' attitude towards online shopping has been confirmed (Liu \& Forsythe, 2010; Yulihasri et al., 2011).

In contrast to the findings of the previous existing literature, the findings of this study show that hedonic motivation has no significant effect on the attitude towards online shopping among the MBA students. These findings, however, contradicted the conclusion drawn by many researchers such as Liu and Forsythe (2010), Sahney et al. (2008) and Sojung and Matthew (2011), which states that the enjoyable experience of the customer influences his or her decision regarding the online shopping.

Generally, the findings of this study might be of value to the practitioners especially those concerning about the marketing issues and business growth. This study could answer questions such as what are the factors that might affect the attitude of the future generations and how can the attitude, subjective norms and the perceived behavioral control affect the intention towards online shopping.

As with other studies dependent on the survey questionnaires to collect the data, this study had some limitations. For example, since the respondents of this study were the MBA students, drawing a generalized conclusion about the market consumer's behavior can be questionable. Future studies should expand the sample of the study to well-represent the population with different customers' segments having different shopping style.

\section{References}

Abdul-Muhmin, A.G. (2011). Repeat Purchase Intentions in Online Shopping: The Role of Satisfaction, Attitude, and Online Retailers' Performance. Journal of International Consumer Marketing, 23, 5-20. http://dx.doi.org/10.1080/08961530.2011.524571

Ajzen, I. (1991). The theory of planned behavior. Organizational Behavior and Human Decision Processes, 50, 179-211. http://dx.doi.org/10.1016/0749-5978(91)90020-T

Ajzen, I., \& Driver, B. L. (1992). Applications of the theory of planned behavior to leisure choice. Journal of Leisure Research, 24, 207-224.

Ajzen, I., \& Madden, T. J. (1986). Prediction of goal-directed behavior: Attitudes, intentions, and perceived 
behavioral control. Journal of Experimental Social Psychology, 22, 453-474. http://dx.doi.org/10.1016/0022-1031(86)90045-4

Alam, S.S., Bakar, Z., Ismail, H.B., \& Ahsan, M.N. (2008). Young consumers online shopping: an empirical study. Journal of Internet Business, 5, 81-98.

Arbuckle, J. (2006). Amos 7.0 User's Guide. Amos Development Corporation: Spring House.

Armstrong, J., \& Overton, T. S. (1779). Estimating nonresponse bias in mail surveys. Journal of Marketing Research, 16, 396-402.

Barclay, D., Higgins, C., \& Thompson, R. (1995). The Partial Least Squares (PLS) Approach to Causal Modeling: Personal Computer Adoption and Use as an Illustration. Technology Studies, 2(2), 285-314.

Bentler, P.M. (2006). EQS 6 structural equations program manual. Encino, CA: Multivariate Software.

Chen, S.J., \& Chang, T.Z. (2003). A descriptive model of online shopping process: some empirical results. International Journal of Service Industry Management, 14(5), 556-569. http://dx.doi.org/10.1108/09564230310500228

Chin, W. W. (1998). The partial least squares approach to structural equation modeling. In G. A. Marcoulides, Modern methods for business research. Mahwah: Lawrence Erlbaum, 295-336.

Chiu, C.M., Chang, C.C., Cheng, H.L., \& Fang, Y.H. (2008). Determinants of customer repurchase intention in online shopping. Online Information Review, 33(4), 761-784. http://dx.doi.org/10.1108/14684520910985710

Chow, W.S., \& Chan, L.S. (2008). Social network and shared goals in organizational knowledge sharing. Information Management, 45(7), 24-30. http://dx.doi.org/10.1108/14684520910985710

Compeau, D.R., Higgins, C.A., \& Huff, S. (1999). Social Cognitive Theory and individual Reactions to Computing Technology - A Longitudinal-Study. MIS Quarterly, 23(2), 145-158. http://dx.doi.org/10.2307/249749

Demangeot, C., \& Broderick, A. J. (2007). Conceptualizing consumer behaviour in online shopping environments. International Journal of Retail \& Distribution Management, 35(11), 878-894. http://dx.doi.org/10.1108/09590550710828218

Dennis, C., Morgan, A., Wright, L.T., \& Jayawardhena, C. (2010). The influences of social e-shopping in enhancing young women's online shopping behavior. Journal of Customer Behaviour, 9(2), 151-174. http://dx.doi.org/10.1362/147539210X511353

Fattahi, S. (2010). Sustainable consumption and purchase intention. Applying the theory of planned behavior. University Multimedia Malaysia. Retrieved from www.vlib.uum.edu.my

Fishbein, M., \& Ajzen, I. (1975). Belief, Attitude, Intentions and Behavior: An Introduction to Theory and Research, Reading, MA. Addison-Wesley, Boston, Massachusetts.

Fornell C., \& Larcker, D.F. (1981). Evaluating structural equation models with unobservable variables and measurement error. Journal of Market Research, 18(1), 39-50. http://dx.doi.org/10.2307/3151312

Fornell, C., \& Cha, J. (1994). Partial least squares. In R. P. Bagozzi (Ed.), Advanced methods of marketing research. Cambridge: Blackwell. pp. 52-78.

Geisser, S. (1975). A predictive approach to the random effect model. Biometrika, 61(1), 101-107. http://dx.doi.org/10.1093/biomet/61.1.101

Götz, O., Liehr-Gobbers, K., \& Krafft, M. (2011). Evaluation of Structural Equation Models Using the Partial Least Squares (PLS) Approach. In V. E. Vinzi, W.W. Chin, J. Henseler, \& H. Wang (Eds), Handbook of Partial Least Squares: Concepts, Methods and Applications. Germany. Springer-Verlag, 691-711.

Hair, J.F., Black, W.C., Babin, B.J., \& Anderson, R.E. (2010). Multivariate Data Analysis. Upper Saddle River, NJ: Prentice-Hall.

Hansen, T. (2008). Consumer values, the theory of planned behaviour and online grocery shopping. International Journal of Consumer Studies, 32, 128-137. http://dx.doi.org/10.1111/j.1470-6431.2007.00655.x

Hsieh, J.Y., \& Liao, P.W. (2011). Antecedents and moderators of online shopping behaviour in undergraduate students. Social Behavior and Personality, 39(9), 1271-1280. http://dx.doi.org/10.2224/sbp.2011.39.9.1271

Jun, G., \& Jaafar, N.I. (2011). A Study on Consumers' Attitude towards Online Shopping in China. International Journal of Business and Social Science, 2(22), 122-132. 
Kannan, V. R., Tan, K-C., Handfield, R. B., \& Ghosh, S. (1999). Tools and techniques of quality management: an empirical investigation of their impact on performance. Quality Management Journal, 6(3), 34-49.

Kim, J., \& Forsythe, S. (2009). Factors affecting adoption of product virtualization technology for online consumer electronics shopping. International Journal of Retail \& Distribution Management, 38(3), 190-204. http://dx.doi.org/10.1108/09590551011027122

Kim, S., \& Eastin, M.S. (2011). Hedonic Tendencies and the Online Consumer: An Investigation of the Online Shopping Process. Journal of Internet Commerce, 10, 68-90. http://dx.doi.org/10.1108/09590551011027122

Kline, R.B. (2011). Principles and Practices of Structural Equation Modelling (3 ${ }^{\text {rd }}$ Ed.). The Guilford Press: USA

Liu, C., \& Forsythe, S. (2010). Sustaining Online Shopping: Moderating Role of Online Shopping Motives. Journal of Internet Commerce, 9, 83-103. http://dx.doi.org/10.1080/15332861.2010.503848

Manafi, M., Hojabri, R., Salehi, M., Khatibi, P., \& Gheshmi, R. (2011). Consumers' Online Shopping Cart Use and its effect on Frequency of Online Buying (Malaysian online Industries). Interdisciplinary Journal of Contemporary Research in Business, 3(4), 954-961.

Mardia, K. (1970). Measures of multivariate skewness and kurtosis with applications. Biometrika, 57, 519- 530. http://dx.doi.org/10.1093/biomet/57.3.519

Morganosky, M.A., \& Cude, B.J. (2000). Consumer response to online grocery shopping. International Journal of Retail \& Distribution Management, 28(1), 17-26. http://dx.doi.org/10.1108/09590550010306737

Naseri, M.B. (2011). Role of demographics, social connectedness and prior internet experience in adoption of online shopping: Applications for direct marketing. Journal of Targeting, Measurement and Analysis for Marketing, 19(2), 69-84. http://dx.doi.org/10.1057/jt.2011.9

Naveed, A. T., \& Eddaoudi, B. (2009). Assessing the Effect of Trust and Security Factors on Consumers' Willingness for Online Shopping among the Urban Moroccans. International Journal of Business and Management Science, 2(1), 17-32.

Rajamma, R. K., \& Neeley, C. R. (2005). Antecedents to shopping online: A Shopping Preference Perspective. Journal of Internet Commerce, 4(1), 63-78. http://dx.doi.org/10.1300/J179v04n01_03

Sahney, S., Shrivastava, A., \& Bhimalingam, R. (2008). Consumer Attitude towards Online Retail Shopping in the Indian Context. The Icfai University Journal of Consumer Behavior, 3(4).

Sekaran, U., \& Bougie, R. (2010). Research Methods for Business: A Skill Building Approach. UK: John Wiley $\&$ Sons.

Stone, M. (1975). Cross-validatory choice and assessment of statistical predictions. Journal of the Royal Statistical Society, 36(2), 111-133.

Su, D., \& Huang, X. (2011). Research on Online Shopping Intention of Undergraduate Consumer in China .Based on the Theory of Planned Behavior. International Business Research, 4(1), 86-92.

Tenenhaus, M., Amato, S., \& Esposito Vinzi, V. (2004). A global goodness-of-fit index for PLS structural equation modeling. Proceedings of the XLII SIS Scientific Meeting (pp. 739-742). CLEUP, Padova.

Wang, M.S., Chen, C.C., Chang, S.C., \& Yang, Y.H. (2007). Effects of Online Shopping Attitudes, Subjective Norms and Control Beliefs on Online Shopping Intentions: A Test of the Theory of Planned Behavior. International Journal of Management, 24(2), 296-302.

Wetzels, M., Odekerken-Schröder, G., \& Oppen, C.V. (2009). Using PLS path modeling for assessing hierarchical models: Guidelines and empirical illustration. MIS Quarterly, 33(1), 177-195.

Wold, H.O.A. (1982). Soft modeling: The basic design and some extensions. In K. G. J"oreskog and H. O. A. Wold (Eds.), Systems under indirect observations: Causality, structure, prediction, Part 2. Amsterdam, The Netherlands: North-Holland. pp. 1-54.

Yulihasri, Islam, M. A., \& Daud, K. A. K. (2011). Factors that Influence Customers' Buying Intention on Shopping Online. IntemationalJoumal of Marketing Studies, 3(1), 128-139. 